The Cryosphere Discuss., doi:10.5194/tc-2016-165, 2016

Manuscript under review for journal The Cryosphere

Published: 14 July 2016

(c) Author(s) 2016. CC-BY 3.0 License.

\title{
Slight glacier reduction over the northwestern Tibetan Plateau despite significant recent warming
}

\author{
Yetang Wang ${ }^{1}$, Shugui Hou², Wenling An², Hongxi Pang ${ }^{2}$, Yaping $\mathrm{Liu}^{3}$ \\ ${ }^{1}$ College of Geography and Environment, Shandong Normal University, Jinan 250014, China
}

$5 \quad{ }^{2}$ Key Laboratory of Coast and Island Development of Ministry of Education, School of Geographic and Oceanographic Sciences, Nanjing University, Nanjing 210093, China

${ }^{3}$ State Key Laboratory of Cryospheric Sciences, Cold and Arid Regions Environmental and Engineering Research Institute, Chinese Academy of Sciences, Lanzhou 730000, China

Correspondence to: Shugui Hou (shugui@nju.edu.cn)

10 Abstract. 'Pamir-Karakoram-Western-Kunlun-Mountain (northwestern Tibetan Plateau) Glacier Anomaly” has been a topic of debate due to the balanced, or even slightly positive glacier mass budgets in the early 21st century. Here we focus on the evolution of glaciers on the western Kunlun Mountain and its comparison with those from other regions of the Tibetan Plateau. The possible driver for the glacier evolution is also discussed. Western Kunlun Mountain glaciers reduce in area by $0.12 \% \mathrm{yr}^{-}$

${ }^{1}$ from 1970s to 2007-2011. However, there is no significant area change after 1999. Averaged glacier thickness loss is

$150.08 \pm 0.09 \mathrm{~m} \mathrm{yr}-1$ from 1970s to 2000, which is in accordance with elevation change during the period 2003-2008 estimated by the ICESat laser altimetry measurements. These further confirm the anomaly of glaciers in this region. Slight glacier reduction over the northwestern Tibetan Plateau may result from more accumulation from increased precipitation in winter which to great extent protects it from mass reductions under climate warming during 1961-2000. Warming slowdown since 2000 happening at this region may further mitigate glacier mass reduction, especially for the early $21^{\text {st }}$ century.

\section{Introduction}

In recent decades, the scientists are debating about global glacier shrinkage and its consequences on sea level rise and the mountain ecosystem (Rees et al., 2006; Immerzeel et al., 2010; Gardelle et al., 2012). The western Kunlun Mountain and its surrounding glaciers are a focus of public and scientific debate (Hewitt, 2005; Kang et al., 2010; Yao et al., 2012; Kääb et al., 2012; Gardelle et al., 2012; Gardner et al., 2013). Glaciers located on the western Kunlun Mountain (WKM), Karakoram and Himalaya represent the largest ice masses in the world, outside the Polar regions (Smiraglia et al., 2007). They are at the headwaters of many prominent rivers and play an important role in the water tower of Asia (Yao et al., 2012). Among these regions, most reports indicate that emerging indications of stability or mass gain in the Karakoram and WKM in the early 21st century (Yao et al., 2012; Kääb et al., 2012; Gardelle et al., 2012; Bolch et al., 2012). In contrast, glaciers in the Himalaya are reported to be diminishing rapidly (Bolch et al., 2011). These contrasting glacier changes may result from a pattern of climatic change in WKM and Karakoram, which is different from that in the Himalaya (Kapnick et al., 2014; Wiltshire et al., 2014). In 
The Cryosphere Discuss., doi:10.5194/tc-2016-165, 2016

Manuscript under review for journal The Cryosphere

Published: 14 July 2016

(c) Author(s) 2016. CC-BY 3.0 License.

fact, the WKM and Himalaya glaciers continue to be interesting to glaciologists, lacking of accurate long span glacier change results and a poor understanding of the processes affecting them, makes imperative deep analysis.

Glacier elevation changes in Himalayas and its surroundings are of major concerns (Bolch et al., 2012). Quantification of these changes are often based on the "geodetic" method (Finsterwalder, 1954; Krimmel et al., 1999; Cox et al., 2004; Haug

5 et al., 2009; Zemp et al., 2010; Fischer et al., 2011) by comparing two maps or DEMs (Digital Elevation Models) of the same area from different years (Arendt et al., 2002; Abdalati et al., 2004; Rivera et al., 2005; DeBeer and Sharp, 2007; Berthier and Toutin, 2008). ICESat (Ice, Cloud and land Elevation Satellite), GRACE (Gravity Recovery and Climate Experiment) combined with Shuttle Radar Topography Mission (SRTM) has been used to estimate glacier thickness changes in the early 21st century (e.g., Zhang et al., 2011; Kääb et al., 2012; Phan et al., 2012; Gardner et al., 2013). The quantification of glacier thickness change for a long span in the WKM is hampered by a lack of sufficiently distributed and accurate repeated surface topography data. So far, there is no reports on the changes in glacier elevation in the WKM before 2000.

In this paper, we address the current state of glaciers and make efforts in understanding glacier change processes in the WKM. The main goals of this paper are to derive decadal glacier area and thickness change, and also to give possible climatic drivers for glaciers change in the WKM region.

\section{Data and methods}

To quantify glacier extent changes in WKM, we collect the glacier outline data from the first glacier inventory in China (CGI1) accomplished in 2002, and the new Chinese glacier inventory (CGI2) freely released in 2014, which is available at http://westdc.westgis.ac.cn/glacier/view/. CGI1 data for WKM are updated by means of manual delineation of glacier extents on the topographic maps (1:100 000) corrected by aerial photographs taken between 1968 and 1976. CGI2 database is

20 constructed using 218 Landsat TM/ETM+ images acquired from 2004 to 2011 based on band ratio segmentation method in combination with manual improvements in accordance with the guidelines of the Global Land Ice Measurements from Space (GLIMS) (Racoviteanu et al., 2009). The resulting glacier extent error is estimated to be $\pm 3.2 \%$ (Guo et al., 2015). The CGI2 data for the WKM were generated using cloud-free Landsat TM scenes obtained between 19 August 2007 and November 2011. We also use a quality-controlled glacier inventory for Asian high mountains (GAMDAM) (Nuimura et al., 2015), which

25 provides manual delineation of glacier outlines over WKM by means of ortho-calibrated Landsat ETM+/TM scenes during 1999-2002, and the Global Land Survey digital elevation model (DEM) 2000 and high resolution Google EarthTM imagery.

Two DEMs from different years are used to evaluate the elevation change between the 1970s and 2000. The DEM in 1968-1976 (hereafter DEM70) was created by interpolating the digitized 50 m equidistant contour lines and elevation points from the topographic maps (1:100 000). The other one is the hole-filled DEM generated by SRTM version 4.1 with C- and X-

30 band SAR from 11 to 22 February 2000 at EGM 96 orthometric heights with $90 \mathrm{~m}$ pixel resolution. We firstly calculate the difference of DEM70 relative to SRTM-DEM by excluding non-stable terrain such as (rock) glaciers, ice-cored moraines, and lakes. Then to minimize the elevation error, DEM70 is co-registrated to SRTM-DEM using the relationship between elevation 
The Cryosphere Discuss., doi:10.5194/tc-2016-165, 2016

Manuscript under review for journal The Cryosphere

Published: 14 July 2016

(c) Author(s) 2016. CC-BY 3.0 License.

difference and aspect (Nuth and Kääb, 2011). The method is performed based on Python programming language by Pieczonka et al. (2013).

Gridded air temperature at $2 \mathrm{~m}$ above ground data for the regions at latitudes 33-39oN, and longitudes 71-82oE covering the WKW and Karakoram from nine reanalyses with varying resolutions are also used, i.e., ECMWF Interim Re-Analysis (ERA-Interim), NASA Modern Era Retrospective-Analysis for Research and Application (MERRA), the Climate Forecast System Reanalysis (CFSR), NOAA Twentieth Century Reanalysis version 2c (20CRv2c), ECMWF pilot reanalysis of the 20th-century assimilating surface observations only (ERA-20C), Goddard Institute for Space Studies Surface temperature analysis (GISS), the Climatic Research Unit Time Series data version 3.23 (CRU3.23), the Global Historical Climatology Network-Monthly version 3.3.0 temperature dataset (GHCN-M v3.3.0), and Climate Prediction Center Global Land Surface

10 Air Temperature Analysis (CPC) (Table 1). Monthly gridded precipitation data come from Global Precipitation Climatology Project (GPCP) Version 2.2 Combined Precipitation Data Set, which combines gauged precipitation with satellite estimate based on Special Sensor Microwave/Imager (SSMI), Special Sensor Microwave Imager/Sounder (SSMIS), Atmospheric Infrared Sounder (AIRS data from the NASA Aqua, Television Infrared Observation Satellite Program (TIROS), Operational Vertical Sounder (TOVS), and Outgoing Longwave Radiation (OLR), etc.

\section{Uncertainty}

The uncertainty of the glacier area is estimated using buffering method. We buffer the glacier polygons for the topographic maps at scale of 1:100 000 (CGI1) with $25 \mathrm{~m}$, and CGI2 and GAMDAM with half of Landsat TM image pixels $(15 \mathrm{~m})$. Then buffered areas are calculated by multiplying total pixel bounded by each buffered glacier polygon and one pixel area. The resulting uncertainty of the glacier areas is $4.3 \%$ for CGI1, and 3\% for CGI2 and GAMDAM.

The uncertainty of the glacier elevation change is calculated using the two DEM difference through non-stable terrain exclusion, and outliers and curvature effects are also considered. Elevation change uncertainty is estimated to be $\pm 0.09 \mathrm{~m}_{\mathrm{yr}^{-}}$ 1.

\section{Results}

The WKM glaciers cover an area of $8817.78 \mathrm{~km} 2$ in 1968-1976, and shrink to $8408.83 \mathrm{~km} 2$ in 2007-2011, indicating 25 rates of area reduction $4.6 \%$ in the last 40 years. According to the GAMDAM glacier inventory, the total area of WKM glaciers is $8380.71 \mathrm{~km} 2$ during 1999-2002. The difference between the area values of 2000s and 2010s is not significant. The decline of surface elevation mainly occurred in the glacier tongue areas (Fig. 2). The surface elevation of the WKM glaciers decline with a rate of $0.08 \pm 0.09 \mathrm{~m}$ yr-1 from 1970s to 2000 .

Glacier changes on the Tibetan Plateau and surrounding regions are spatially heterogeneous (Fig. 1). Glaciers in the 30 Tienshan Mountains decrease in their area by $\sim 0.35 \% \mathrm{yr}^{-1}$ from 1961 to 2012. Rapid glacier shrinkage also occurs over the 
The Cryosphere Discuss., doi:10.5194/tc-2016-165, 2016

Manuscript under review for journal The Cryosphere

Published: 14 July 2016

(c) Author(s) 2016. CC-BY 3.0 License.

southeastern and northeastern Tibetan Plateau and the Himalayan regions. The area decrease on the Himalayas is $\sim 0.4 \% \mathrm{yr}^{-}$

${ }^{1}$. Over the Hengduan Shan, area decrease rate reach $\sim 0.57 \% \mathrm{yr}^{-1}$. Based on the two Chinese glacier inventories, the decreases in glacier extent over the Qilian Mountain and Kailas Range are estimated to be $\sim 0.42 \% \mathrm{yr}^{-1}$ and $\sim 0.73 \% \mathrm{yr}^{-1}$ from the 1950 s to 2004-2011, respectively. The decrease in glacier area on the Tibetan Plateau interior, often termed as the Qangtang Plateau 5 is relatively small ( $\sim .24 \% \mathrm{yr}^{-1}$ from 1970s to 2004-2011) (Wei et al., 2014). Compared to the regions described above, glacier areas on the northwestern Tibetan Plateau are most stable. Over WKW, the area reduction rate is only $0.12 \% \mathrm{yr}^{-1}$ during the last 40 years. In Central Karakoram National Park, glacier area increases slightly by 0.4 km2 between 2001 and 2010 (Minora et al., 2016). For the whole Karakoram, only 8 \% of the glaciers recess from 1976 to 2012 (Rankl et al., 2014). It is apparent that glaciers on the western, especially the northwestern Tibetan Plateau remain stable.

\section{Discussion}

Difference in glacier variation at different regions may be related to a larger-scale meteorological or climatic feature, and peculiarities of the regional topography or glacier attributions (e.g. size, type, hypsometry, avalanche contribution; Hewitt, 2011). Temperature is one of the most important factors controlling the glacier changes. On the Tibetan Plateau, the highest warming rates often occur between 4,800 and 6,200 m a.s.l. (Yao et al., 2012). This elevation range contains the ablation

15 altitudes of nearly all glaciers over the Plateau. We collect weather station records (1961-2014) over the Tibetan Plateau to estimate air temperature variation. The annual mean temperature shows significant increasing trends in most regions on the Tibetan Plateau (Fig.3) during the periods of 1961-2000 and 1961-2014. However, from 2000 to 2014, the significant increasing trends are only detected in some stations on the southern and eastern Tibetan Plateau. Meanwhile, the stations on the western and northern Tibetan Plateau show insignificantly decreasing trends, indicating a reduced warming in these regions during recent decade. It is clear that the meteorological stations on the northwestern Tibetan Plateau are scarce, especially for the high mountain regions. To further determine the air temperature variability over northwestern Tibetan Plateau, the nine high-resolution reanalyses for this region $\left(33-39^{\circ} \mathrm{N}, 71-82^{\circ} \mathrm{E}\right)$ are compared to the available observations, and $\delta 18 \mathrm{O}$ records from ice cores drilled on Chongce ice cap and Zangser Kangri (ZSKG) glacier (An et al., 2016a; An et al., 2016b, revised). The results further confirm that the temperature variations showed little change from 2000 to 2014 for the northwestern Tibetan Plateau (Fig. 4).

Precipitation is an important factor influencing the glacier variations on the Tibetan Plateau. It is mainly controlled by the interplay between the Indian monsoon in summer and the westerlies in winter (Yao et al., 2012). Recent studies suggested weakening Indian monsoon and strengthening westerlies during the past decades (e.g., Yao et al., 2012). We use the gridded precipitation fields from GPCP to examine the trends of annual and winter precipitation on the Tibetan Plateau during the period 1979-2014. Significantly upward annual precipitation trends exceed $6 \mathrm{~mm}$ yr-1 over the northwestern Tibetan Plateau (WKM and Karakoram), and significantly downward trends ( $\left.>7 \mathrm{~mm} \mathrm{yr}^{-1}\right)$ happen over the Himalayas and Hengduan Shan. On winter, WKM and Karakoram also experience significant precipitation increase (Fig.5). Recently, Kapnick et al. (2014) 
The Cryosphere Discuss., doi:10.5194/tc-2016-165, 2016

Manuscript under review for journal The Cryosphere

Published: 14 July 2016

(c) Author(s) 2016. CC-BY 3.0 License.

found that over Karakoram, its climatic seasonal cycle is dominated by non-monsoonal winter precipitation, which is different from the other regions on the Tibetan Plateau where glacier is type of summer monsoon accumulation. The same pattern also occurs on the WKM (not shown). Increase in precipitation especially during winter season may to great extent offset the effect of recent warming on the glacier variations over the northwestern Tibetan Plateau.

Previous studies suggest that the magnitude and timescale of a glacier's response to climate change also depend on factors such as its size, surface slope, direction and its debris cover. Generally, larger and flatter glaciers tend to smooth the climatic signal, and respond to climate change with a delay of several decades (Kirkbride and Winkler, 2012). This is the case for glaciers over the northwestern Tibetan Plateau (Shi, 2008). In addition, the debris cover could slow down a glacier's response to climate warming by influencing its melt rate and terminus dynamics (Bhambri et al., 2013; Collier et al., 2013;

10 Gardelle et al., 2012). The mean debris cover is up to $10 \%$ of the total glacial area in the Karakoram and Himalaya (Scherler et al., 2011). Scherler et al. (2011) concluded that the distinct response of Himalayan glaciers to climate change was partly attributed to differences in topographic variations and debris cover. However, Bhambri et al. (2013) found that the overall area covered by debris was only around $1.2 \%$ of the whole ice cover over the northeast Karakoram. In addition, when examining the slight mass gain of Karakoram glaciers during the early 21st century, Gardelle et al. (2012) found that ice thinning and

15 ablation at high rates could still occur on debris-covered glacier tongues. Therefore, these factors could not explain the observed disparity between significant recent warming and weak change of glaciers over the northwestern Tibetan Plateau, owing to their extensive size and low debris cover (Yao et al., 2012; Scherler et al., 2011).

Based on the difference of DEM70 relative to SRTM-DEM, averaged elevation change is $-0.08 \pm 0.09 \mathrm{~m} \mathrm{yr}^{-1}$ for the glaciers on the WKM region from 1970s to 2000. Similarly, in relation to SRTM-DEM, ICESat laser altimetry measurements

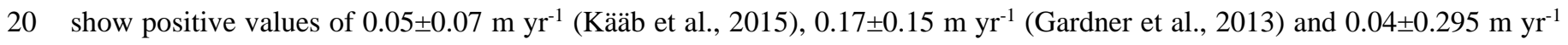
(Neckel et al., 2014) for glacier elevation changes from 2003 to 2009. At Muztagh Ata (eastern Pamir), geodetic measurements show the averaged glacier mass budgets are slightly but insignificantly negative between 1973 and 1999 and positive after 1999 (Holzer et al., 2015). Slight mass gain observation during the 2000s may reflect a regional-wide positive anomaly with increasing precipitation. In addition, the relative stable status of the glaciers in this region could be associated with regional

25 air temperature variations. We find that the temperature variations show little change from 2000 to 2012 for the northwestern Tibetan Plateau, compared with that during the period 1970-1999 as described above. In contrast, the temperature variations on the eastern Tibetan Plateau show persistent and strengthening warming in recent decade. This reveals that the warming slowdown may have partly result in the weak changes in glacier area and elevation of glaciers on the northwestern Tibetan Plateau in the early 21st century.

\section{Conclusions}

The analysis of the area changes reveals slight reduction ( 4.6\%) of the WKM glaciers in the last 40 years, and also shows area stability after 1999, evidence of the anomaly of glaciers in the WKM in contrast to a worldwide reduction of 
The Cryosphere Discuss., doi:10.5194/tc-2016-165, 2016

Manuscript under review for journal The Cryosphere

Published: 14 July 2016

(c) Author(s) 2016. CC-BY 3.0 License.

mountain glaciers in the early $21^{\text {st }}$ century. Compared with the other regions of Tibetan Plateau, northwestern Tibetan Plateau may experience the least glacier reduction. This is beneficial for paleoclimate studies using ice core records because dramatic loss of glacier accumulation area at Nyainqêntanglha Mountain and Geladaindong Mountain, even from the southern to central Tibetan Plateau at high elevations in recent decades results in the removal of records for several decades and even more (Kang 5 et al., 2015).

The slight reduction of glacier over the northwestern Tibetan Plateau may be associated with peculiarities of the regional meteorological or climatic feature. More accumulation from increased winter precipitation partly offsets the glacier reduction resulting from significant warming during 1961-2000. Warming slowdown since 2000 happening this region also contribute to the slight glacier reduction, even mass gaining, especially for the early 21st century.

\section{Acknowledgments}

This work was supported by the Natural Science Foundation of China (41330526, 41171052 and 41321062) and the Chinese Academy of Sciences (XDB03030101-4).

\section{References}

Abdalati, W., Krabill, W., Frederick, E., Manizade, S., Martin, C., Sonntag, J., Swift, R., Thomas, R., Yungel, J., and Koerner, R.: Elevation changes of ice caps in the Canadian Arctic Archipelago, J. Geophys. Res., 109, F04007, 2004.

An, W., Hou, S., Zhang, W., Wang, Y., Wu, S. and Pang, H.: Significant recent warming over the northern Tibetan Plateau from ice core $\delta^{18} \mathrm{O}$ records, Clim. Past. 12, 1-11, 2016a.

An, W., Hou, S., Zhang, W., Wu, S., Xu H., Pang, H., Wang, Y., and Liu, Y.: Possible recent warming hiatus on the northwestern Tibetan Plateau derived from ice core records, Scientific Rep., 2016b, revised.

20 Arendt, A. A., Echelmeyer, K. A., Harrison, W. D., Lingle, C. S., and Valentine, V. B.: Rapid wastage of Alaska glaciers and their contribution to rising sea level, Science, 297, 382- 386, 2002.

Bhambri, R., Bolch, T., Kawishwar, P., Dobhal, D. P., Srivastava, D., and Pratap, B.: Heterogeneity in glacier response in the upper Shyok valley, northeast Karakoram, The Cryosphere, 7, 1385-1398, 2013.

Bolch, T., Pieczonka, T., and Benn, D.: Multi-decadalmass loss of glaciers in the Everest area (Nepal Himalaya) derived from stereo imagery, The Cryosphere, 5, 349-358, 2011.

Bolch, T., Kulkarni, A., Kääb, A., Huggel, C., Paul, F., Cogley, J. G., Frey, H., Kargel, J. S., Fujita, K., Scheel, M., Bajracharya, S., and Stoffel, M.: The state and fate of Himalayan glaciers, Science, 366, 310-314, 2012. 
The Cryosphere Discuss., doi:10.5194/tc-2016-165, 2016

Manuscript under review for journal The Cryosphere

Published: 14 July 2016

(c) Author(s) 2016. CC-BY 3.0 License.

Collier, E., Mölg, T., Maussion, F., Scherer, D., Mayer, C., and Bush, A. B. G.: High-resolution interactive modelling of the mountain glacier-atmosphere interface: an application over the Karakoram, The Cryosphere, 7, 779-795, 2013.

Cox, L. H., and March R. S.: Comparison of geodetic and glaciological mass balance techniques, Gulkana Glacier, Alaska, USA, J. Glaciol., 50, 363-370, 2004.

5 DeBeer, C. M., and Sharp, M. J.: Glacier area and volume changes in the Canadian Cordillera, Ann. Glaciol., 46, 215-221, 2007.

Finsterwalder, R.: Photogrammetry and glacier research with special reference to glacier retreat in the eastern Alps, J. Glaciol, 2, 306-315, 1954.

Fischer, A., Schneider, H., Merkel, G., and Sailer, R.: Comparison of direct and geodetic mass balances on an annual time scale, The Cryosphere Discuss., 5, 565-604, 2011.

Gardelle, J., Berthier, E. and Arnaud, Y.: Slight mass gain of Karakoram glaciers in the early 21st century, Nature Geosci., 5, 322-325, 2012.

Gardner, A. S., Moholdt, G., Cogley, J. G., Wouters B., Arendt, A. A., Wahr, J., Berthie, E., Hock, R., Pfeffer W. T., Kaser, G., Ligtenberg, S. R. M., Bolch, T., Sharp, M. J., Hagen, J. O., van den Broeke, M. R., and Paul, F.: A Reconciled Estimate of Glacier Contributions to Sea Level Rise: 2003 to 2009, Science, 340, 852, 2013.

Guo, W., Liu, S., Xu, J., Wu, L., Shangguan, D., Yao, X., Wei, J., Bao, W., Yu, P., Liu Q., and Jiang, Z.: The second Chinese glacier inventory: data, methods and results, J. Glaciol., 61, 357-372, 2015.

Haug T., Rolstad C., Elvehøy H., Jackson, M., and Maalen Johansen, I.: Geodetic mass balance of the western Svartisen icecap, Norway, in the periods 1968-1985 and 1985-2002, Ann. Glaciol., 50, 119-125, 2009.

20 Hewitt, K.: The Karakoram anomaly? Glacier expansion and the "elevation effect," Karakoram Himalaya, Mt. Res. Dev, 25, 332-340, 2005.

Holzer, N., Vijay, S., Yao, T., Xu, B., Buchroithner M., and. Bolch, T.: Four decades of glacier variations at Muztagh Ata (eastern Pamir): a multi-sensor study including Hexagon KH-9 and Pléiades data, The Cryosphere, 9, 2071-2088, 2015.

Immerzeel, W. W., van Beek, L. P. H., and Bierkens, M. F. P.: Climate change will affect the Asian water towers, Science, 328, 1382-1385, 2010. 
The Cryosphere Discuss., doi:10.5194/tc-2016-165, 2016

Manuscript under review for journal The Cryosphere

Published: 14 July 2016

(c) Author(s) 2016. CC-BY 3.0 License.

Kääb, A., Berthier, E., Nuth, C., J Gardelle, and Arnaud, Y.: Contrasting patterns of early twenty-first-century glacier mass change in the Himalayas, Nature, 488, 495-498, 2012.

Kääb, A., Treichler, D., Nuth, C., and Berthier, E.: Brief Communication: Contending estimates of 2003-2008 glacier mass balance over the Pamir-Karakoram-Himalaya, The Cryosphere, 9, 557- 564, doi:10.5194/tc-9-557-2015, 2015.

5 Kang, S., Xu, Y., You, Q., Flügel, W.A., Pepin, N., and Yao, T.: Review of climate and cryospheric change in the Tibetan Plateau. Environ. Res. Lett., 5, 015101, 2010.

Kang, S., Wang, F., Morgenstern, U., Zhang, Y., Grigholm, B., Kaspari, S., Schwikowski, M., Ren, J., Yao, T., Qin D., and Mayewski, P. A.: Dramatic loss of glacier accumulation area on the Tibetan Plateau revealed by ice core tritium and mercury records, The Cryosphere, 9, 1213-1222, 2015.

10 Kapnick, S. B., Delworth, T. L., Ashfaq, M., Malyshev, S., and Milly P. C. D.: Snowfall less sensitive to warming in Karakoram than in Himalayas due to a unique seasonal cycle, Nature Geosci., 7, 834-840, 2014.

Kirkbride, M. P., and Winkler, S.: Correlation of Late Quaternary moraines: impact of climate variability, glacier response, and chronological resolution, Quaternary Sci. Rev., 46, 1-29, 2012.

Krimmel, R. M.: Analysis of Difference between Direct and Geodetic Mass Balance Measurements at South Cascade Glacier, Washington, Geogr. Ann. A., 81, 653-658, 1999.

Minora, U., Bocchiola D., D’Agata, C.,Maragno, D., Mayer, C., Lambrecht, A., Vuillermoz, E., Senese, A., Compostella, C., Smiraglia, C., and Diolaiuti G. A.: Glacier area stability in the Central Karakoram National Park (Pakistan) in 2001-2010: The “Karakoram Anomaly”' in the spotlight, Pro. Phys. Geog., 1-32, doi: 10.1177/0309133316643926, 2016.

Neckel, N., Kropacek, J., Bolch, T., and Hochschild, V.: Glacier mass changes on the Tibetan Plateau 2003-2009 derived from ICESat laser altimetry measurements, Environ. Res. Lett., 9, 014009, doi:10.1088/1748-9326/9/1/014009, 2014.

Nuimura, T., Sakai, A., Taniguchi, K., Nagai, H., Lamsal, D., Tsutaki, S., Kozawa, A., Hoshina, Y., Takenaka, S., Omiya, S., Tsunematsu, K., Tshering, P., and Fujita, K.: The GAMDAM Glacier Inventory: a quality controlled inventory of Asian glaciers, The Cryosphere, 9, 849-864, doi:10.5194/tc-9-849-2015, 2015.

Nuth, C. and Kääb, A.: Co-registration and bias corrections of satellite elevation data sets for quantifying glacier thickness change, The Cryosphere, 5, 271-290, doi: 10.5194/tc-5-271-2011, 2011. 
The Cryosphere Discuss., doi:10.5194/tc-2016-165, 2016

Manuscript under review for journal The Cryosphere

Published: 14 July 2016

(c) Author(s) 2016. CC-BY 3.0 License.

(c) (i)

Phan, V. H., Lindenbergh, R., and Menenti, M.: Icesat derived elevation changes of Tibetan lakes between 2003 and 2009, Int.

J. Appl. Earth. Obs. Geoinf., 17, 12-22, 2012.

Pieczonka, T., Bolch, T., Wei, J., and Liu, S.: Heterogeneous mass loss of glaciers in the Aksu-Tarim Catchment (Central Tien Shan) revealed by 1976 KH-9 Hexagon and 2009 SPOT-5 stereo imagery, Remote Sens. Environ., 130, 233-244, 2013.

5 Racoviteanu, A. E., Paul, F., Raup, B., Khalsa, S. J. S., and Armstrong, R.: Challenges and recommendations in mapping of glacier parameters from space: results of the 2008 Global Land Ice Measurements from Space (GLIMS) workshop, Boulder, Colorado, USA. Ann. Glaciol., 50, 53-69, doi: 10.3189/172756410790595804, 2009.

Rankl, M., Kienholz, C., and Braun, M.: Glacier changes in the Karakoram region mapped by multimission satellite imagery, The Cryosphere, 8, 977-989, doi: 10.5194/tc-8-977-2014, 2014.

10 Rivera, A., Casassa, G., Bamber, J. and Kääb, A..: Ice elevation changes in the Southern Patagonia Icefield, using ASTER DEMs, aerial photographs and GPS data. J. Glaciol., 51, 105-112, 2005.

Scherler, D., Bookhagen, B. and Strecker, M. R.: Spatially variable response of Himalayan glaciers to climate change affected by debris cover, Nature Geosci., 4, 156-159, 2011.

Shi, Y. F.: Concise Glacier Inventory of China, Shanghai Science Press, 2008.

15 Smiraglia, C., Mayer, C., Mihalcea C., Diolaiuti, G., Belò, M., and Vassena, G.: Ongoing variations of Himalayan and Karakoram glaciers as witnesses of global changes: recent studies on selected glaciers, Earth Surface Pro., 10, 235-247, 2007.

Wei, J. F., Liu, Shiyin, Guo, Wanqin, Yao, Xiaojun, Xu, Junli, Bao, Weijia, and Jiang, Zongli.: Surface-area changes of glaciers in the Tibetan Plateau interior area since the 1970s using recent Landsat images and historical maps, Ann. Glaciol., 55, 213222, 2014.

Wiltshire, A. J.: Climate change implications for the glaciers of the Hindu Kush, Karakoram and Himalayan region, The Cryosphere, 8, 941-958, 2014.

Yao, T., Thompson, L., Yang, W., Yu, W., Gao, Y., Guo, X., Yang, X., Duan, K., Zhao, H., Xu, B., Pu, J., Lu, A., Xiang, Y., Kattel, D. B., and Joswiak, D.: Different glacier status with atmospheric circulations in Tibetan Plateau and surroundings, Nat. Clima. Change, 2, 663-667, 2012. 
The Cryosphere Discuss., doi:10.5194/tc-2016-165, 2016

Manuscript under review for journal The Cryosphere

Published: 14 July 2016

(c) Author(s) 2016. CC-BY 3.0 License.

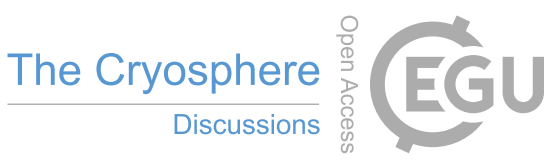

(c) (i)

Zemp, M., Jansson, P., Holmlund, P., Gartner-Roer, I., Koblet, T., Thee, P., and Haeberli, W.: Reanalysis of multi-temporal aerial images of Storglaciren, Sweden (1959-99)-Part 2: Comparison of glaciological and volumetric mass balances, The Cryosphere, 4, 345-357, 2010.

Zhang G., Xie, H., Kang, S., Yi, D., Ackley, S. F.: Monitoring lake level changes on the Tibetan Plateau using icesat altimetry data (2003-2009), Remote Sens. Environ., 115, 1733-1742, 2011. 
The Cryosphere Discuss., doi:10.5194/tc-2016-165, 2016

Manuscript under review for journal The Cryosphere

Published: 14 July 2016

(c) Author(s) 2016. CC-BY 3.0 License.
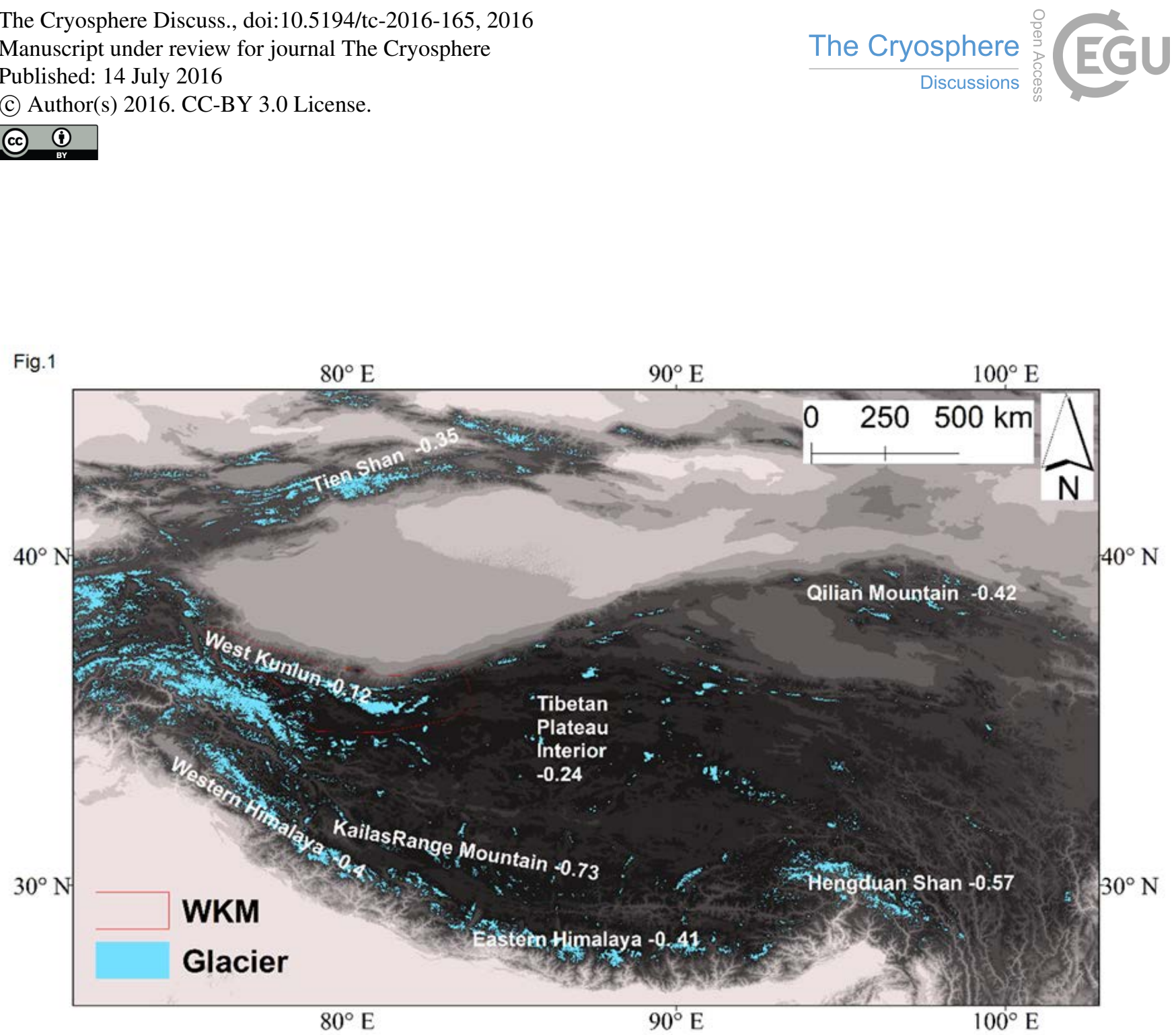

Figure 1 Spatial patterns of glacier area change (\% yr-1) over the Tibetan Plateau and surroundings. Glacier extent changes on the Western Kunlun Mountain, Qilian Mountain and Kailas Range Mountain are determined based on the CGI1 and CGI2 datasets. Changes in glaciers on the Tienshan are from Farinotti et al. (2015), the Tibetan Plateau interior from Wei et al. (2014), and the western and eastern Himalaya and Hengduan Shan from Yao et al. (2012), respectively. 
The Cryosphere Discuss., doi:10.5194/tc-2016-165, 2016

Manuscript under review for journal The Cryosphere

Published: 14 July 2016

(c) Author(s) 2016. CC-BY 3.0 License.

(c) $\underset{0}{(1)}$

Fig. 2

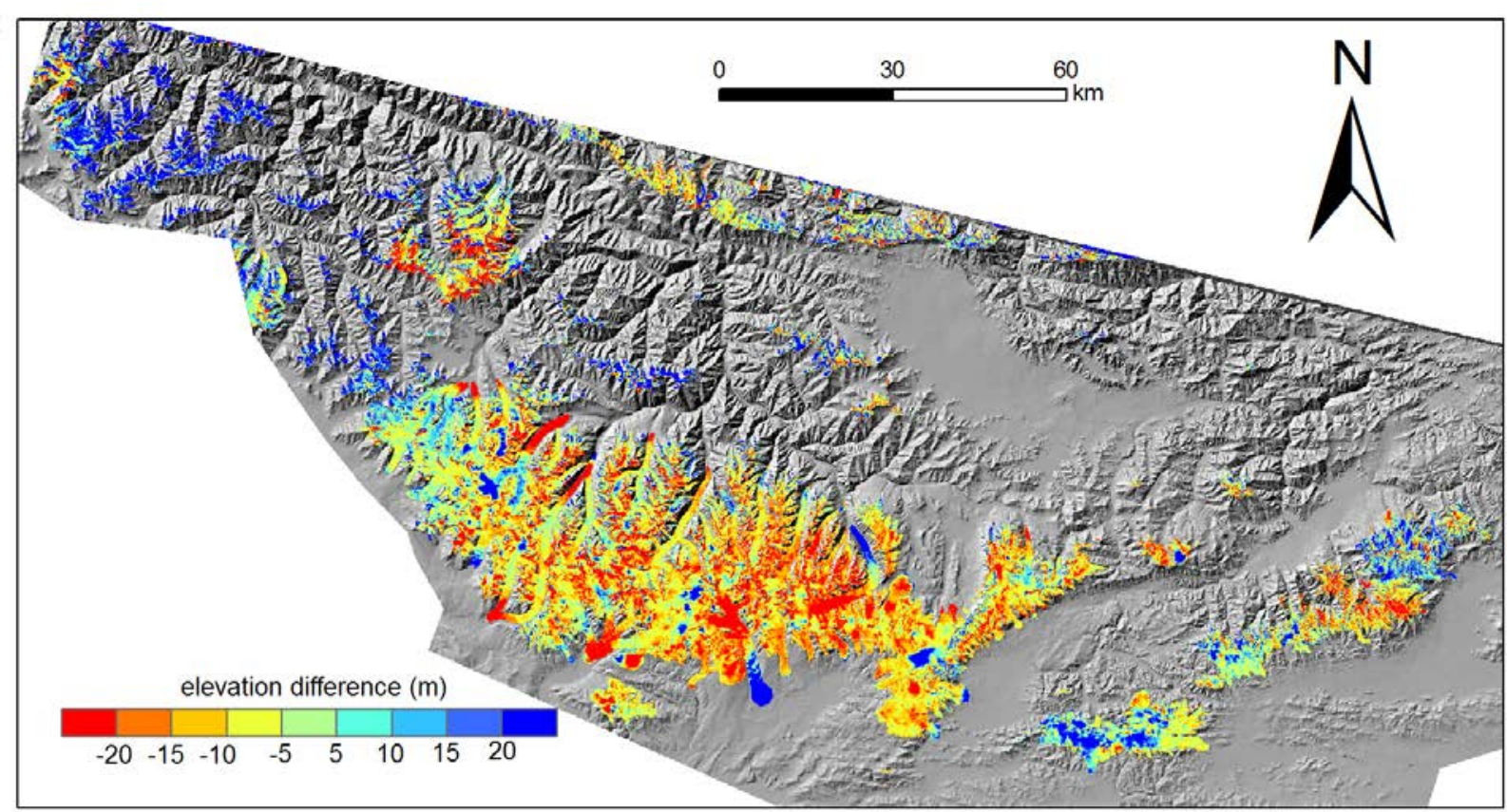

5

Figure 2 Surface elevation changes in the Western Kunlun Mountain 
The Cryosphere Discuss., doi:10.5194/tc-2016-165, 2016

Manuscript under review for journal The Cryosphere

Published: 14 July 2016

(c) Author(s) 2016. CC-BY 3.0 License.

(c) (i)
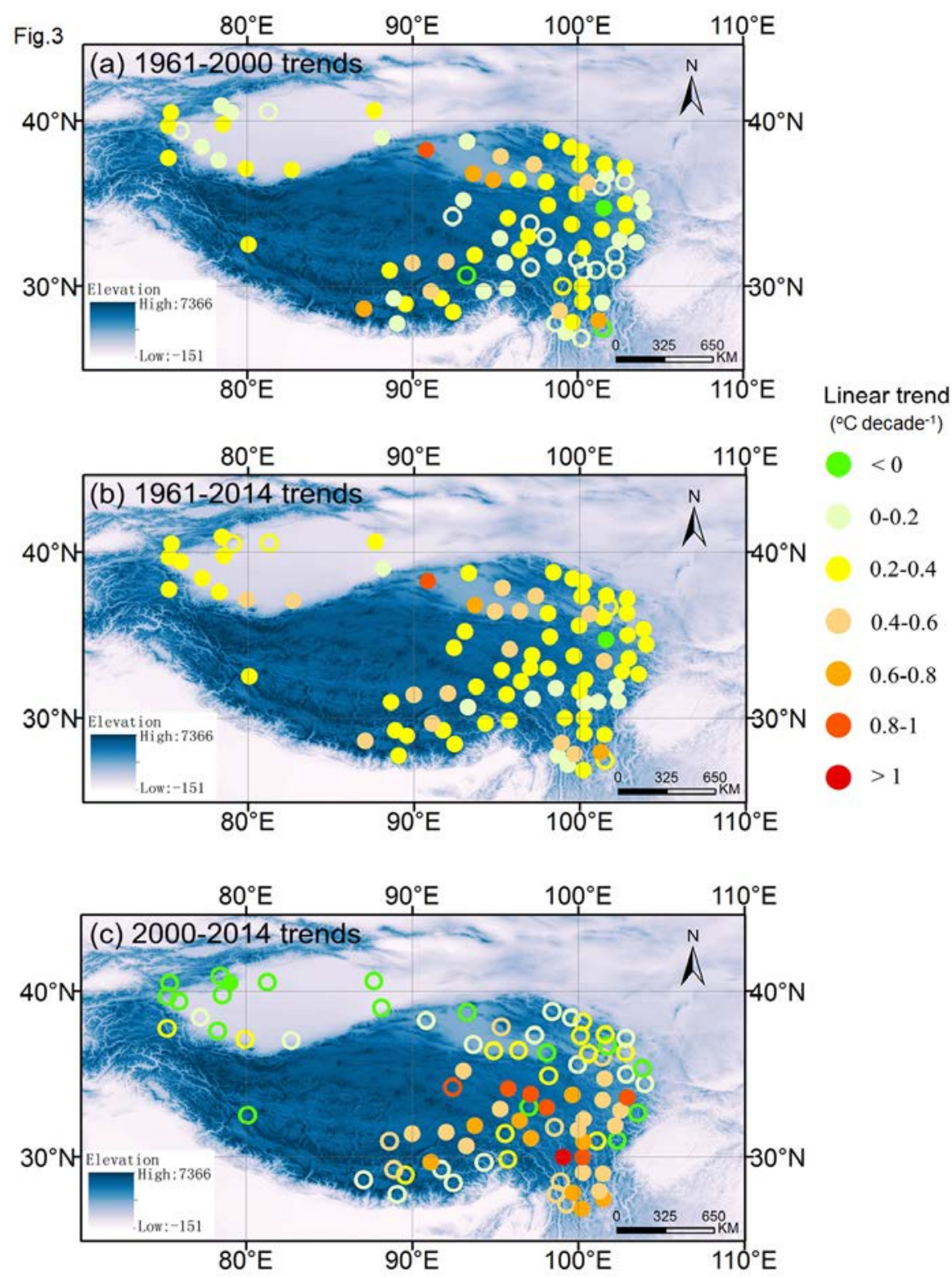

Figure 3 Spatial distribution of linear trends from meteorological stations on the Tibetan Plateau during the different time spans: (a) 1961-2000, (b) 1961-2014, and (c) 2000-2014. The circles indicate the linear trend of annual mean temperature 5 series $\left({ }^{\circ} \mathrm{C}\right.$ decade $\left.^{-1}\right)$. Filled circles indicate trends that are statistically significant at $95 \%$ confidence level based on two-tailed Student's t test. Open circles show trends that are statistically insignificant below 95\% confidence intervals. 
The Cryosphere Discuss., doi:10.5194/tc-2016-165, 2016

Manuscript under review for journal The Cryosphere

Published: 14 July 2016

(c) Author(s) 2016. CC-BY 3.0 License.

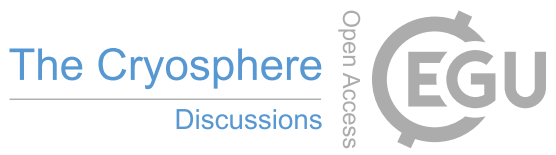

(c) (i)

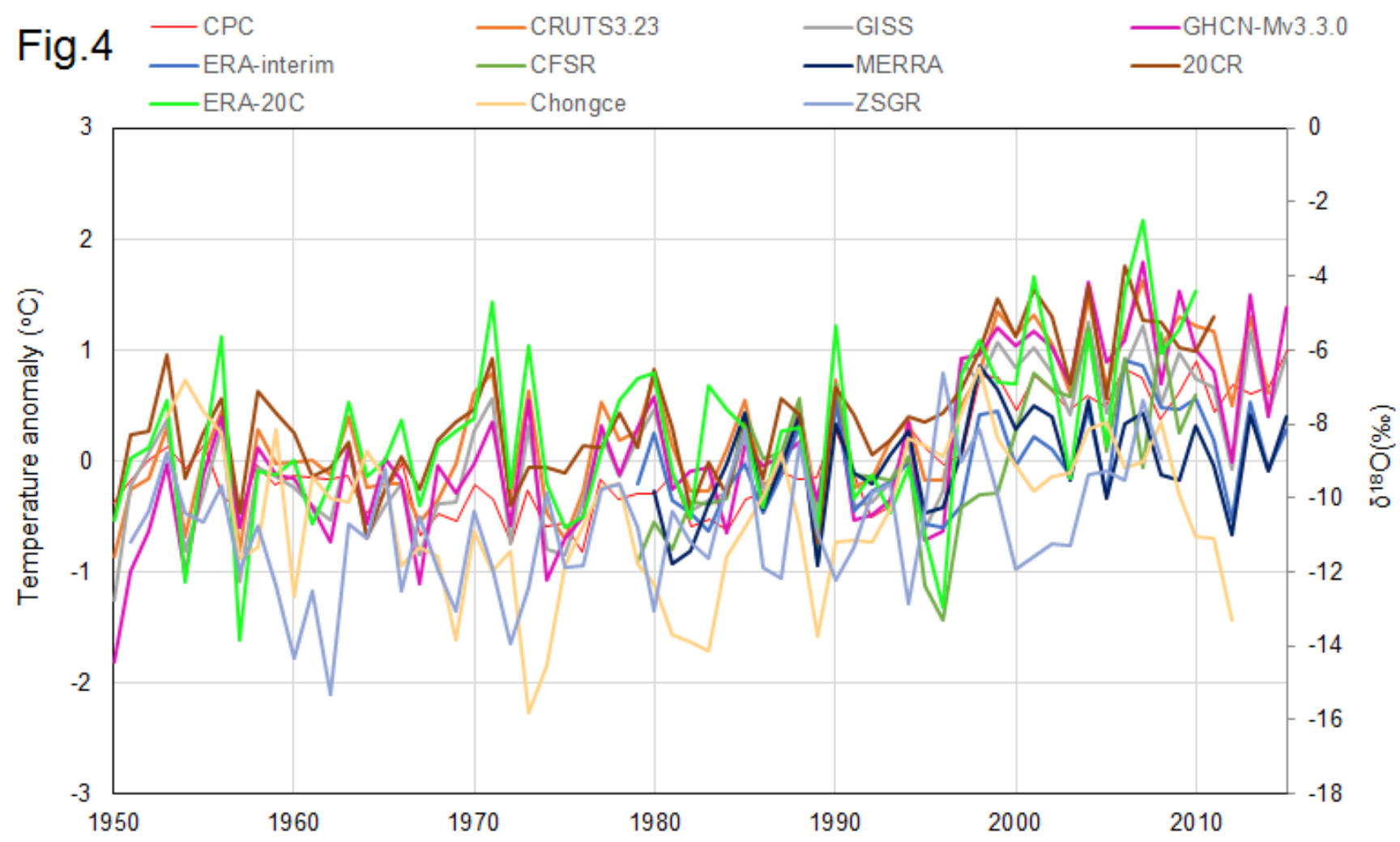

Figure 4 Time series of $\delta^{18} \mathrm{O}$ records from Chongce and ZSKR ice cores from An et al. (2016a), and An et al., (2016b, revised), and air temperature from nine reanalyses for the northwestern Tibetan Plateau (33-39 $\left.\mathrm{N}, 71-82^{\circ} \mathrm{E}\right)$ including ERA-Interim, MERRA, CFSR, GISS, 20CR, ERA-20C, CRU, GHCN-M, and CPC. 
The Cryosphere Discuss., doi:10.5194/tc-2016-165, 2016

Manuscript under review for journal The Cryosphere

Published: 14 July 2016

(c) Author(s) 2016. CC-BY 3.0 License.

(c) (1)

Fig.5

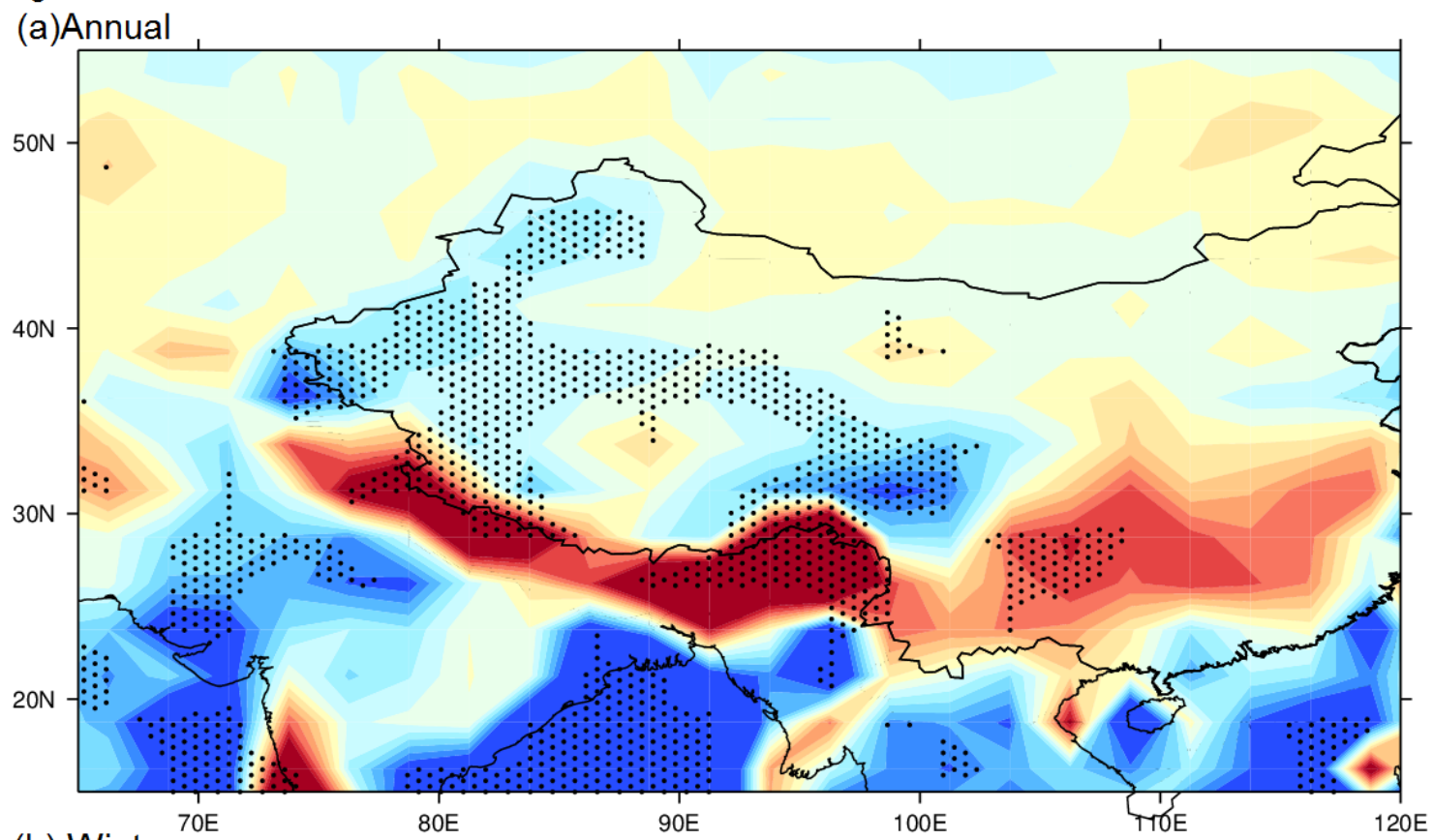

(b) Winter

$80 \mathrm{E} \quad 90 \mathrm{E}$

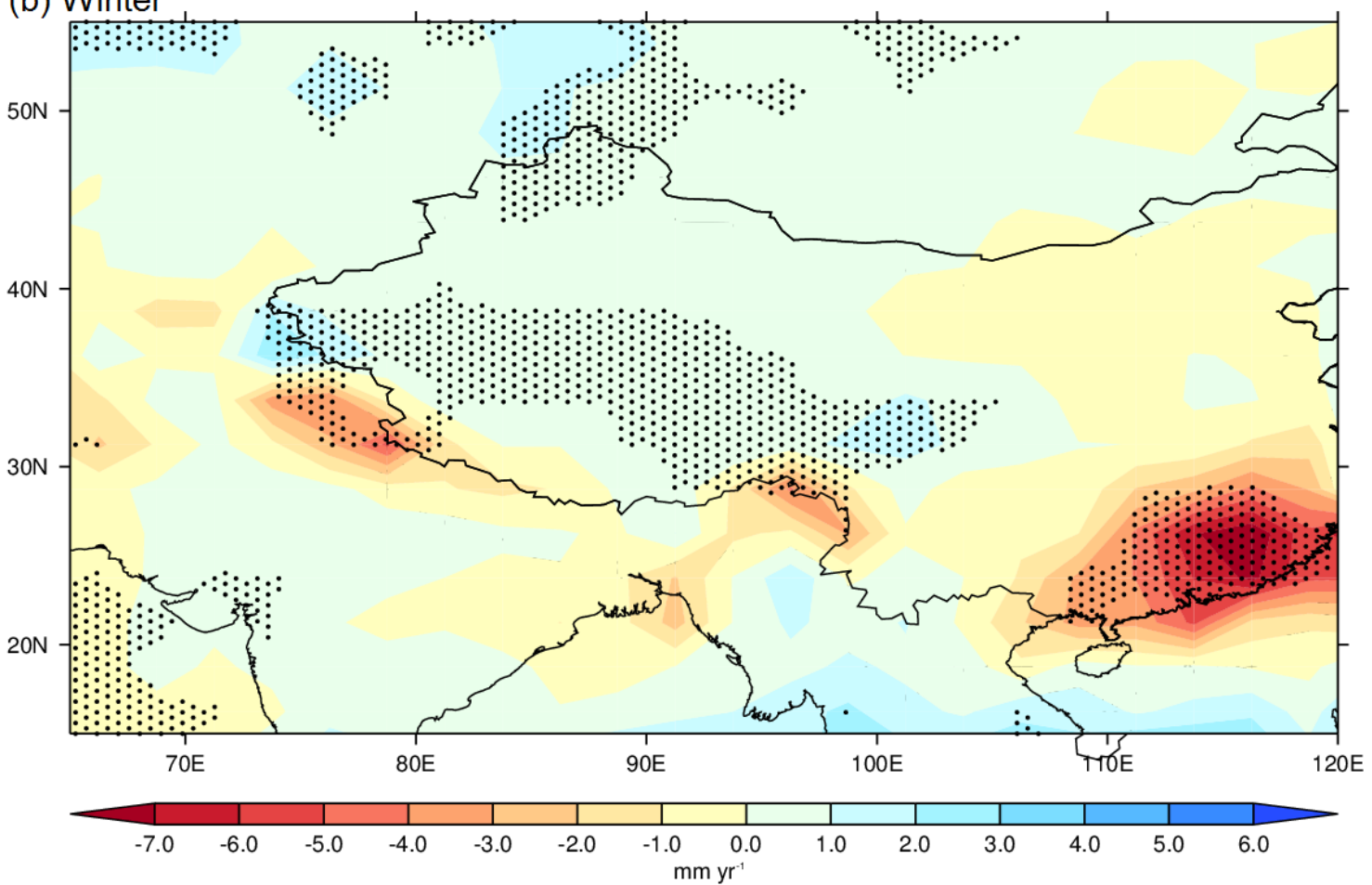

Figure 5 Linear trend of winter and annual precipitation during the period 1979-2014 from GPCP. Dotted areas denote trends that are statistically above 95\% confidence level. 
The Cryosphere Discuss., doi:10.5194/tc-2016-165, 2016

Manuscript under review for journal The Cryosphere

Published: 14 July 2016

(c) Author(s) 2016. CC-BY 3.0 License.

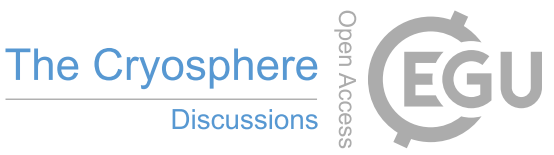

(c) (i)

Table 1 Summary of the reanalyses used in this study.

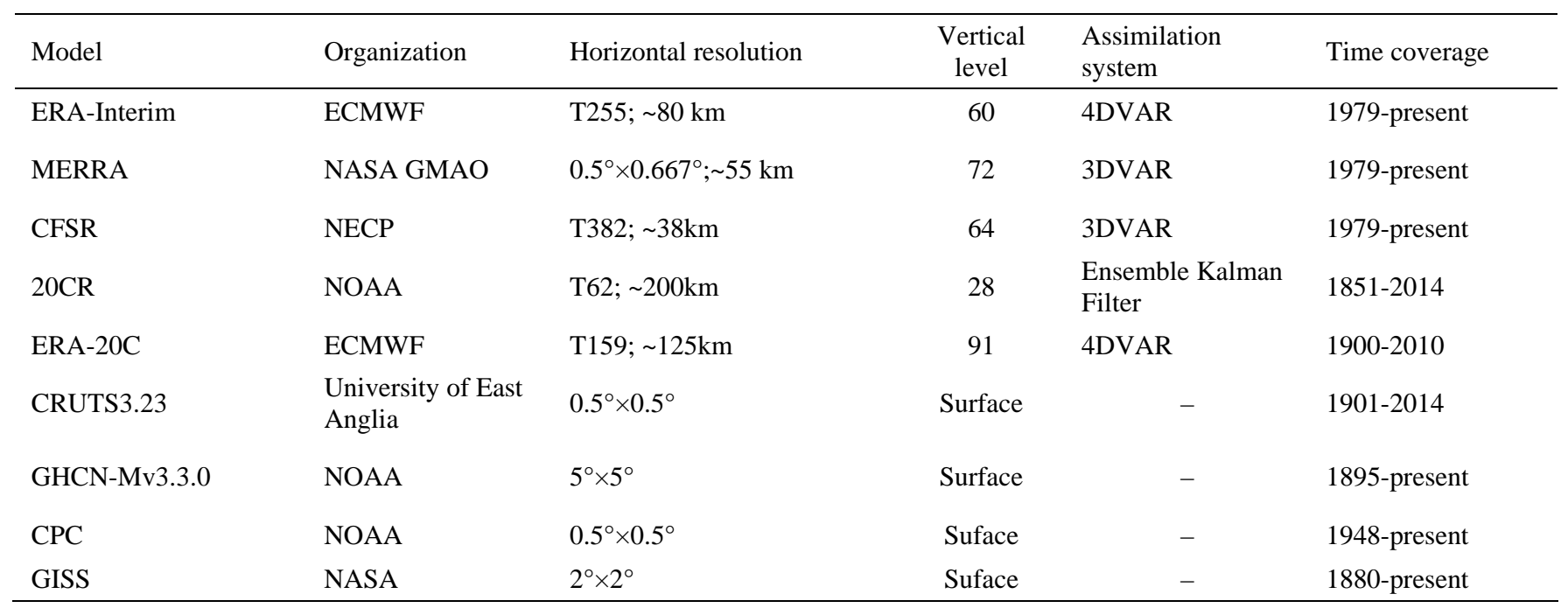

